Article

\title{
Agricultural Internet Entrepreneurs' Social Network Behaviors and Entrepreneurship Financing Performance
}

\author{
Zichun Yan ${ }^{1}$, Kai Wang ${ }^{2, *}$, Ze-Yu Wang ${ }^{3, *}$, Jian Yu ${ }^{4}$, Sang-Bing Tsai ${ }^{5}$ (1) and Guodong Li $^{1}$ \\ 1 Economics and Management College, Civil Aviation University of China, Tianjin 300300, China; \\ xmairline@126.com (Z.Y.); gdli@cauc.edu.cn (G.L.) \\ 2 College of Business Administration, Capital University of Economics and Business, Beijing 100070, China \\ 3 Institute of Economics, Chinese Academy of Social Science, Beijing 100045, China \\ 4 Research Center for Environment and Sustainable Development of the China Civil Aviation, Civil Aviation \\ University of China, Tianjin 300300, China; yjian@cauc.edu.cn \\ 5 Zhongshan Institute, University of Electronic Science and Technology of China, Zhongshan 528402, China; \\ sangbing@hotmail.com \\ * Correspondence: wangkai@cueb.edu.cn (K.W.); wangzeyu@cass.org.cn (Z.-Y.W.)
}

Received: 20 June 2018; Accepted: 21 July 2018; Published: 31 July 2018

check for updates

\begin{abstract}
From the perspective of social network behavior, our paper discusses the relationship between agricultural entrepreneurial social network behavior and entrepreneurial financing performance in an Internet crowdfunding setting, and investigates the moderating role of entrepreneurial team size. In this paper, the data-mining method is used to capture and collate data regarding 7585 venture projects on an Internet crowdfunding platform between 2014 and 2017. Ordinary least squares (OLS) and Probit models are applied to the empirical test. The results show that first, compared with other industries, the effect of agricultural entrepreneurs' quality information disclosure on entrepreneurship financing performance is lower, whereas the effect of their social network interaction is higher. Second, the entrepreneurial team size has a positive moderating role on the former and a negative moderating role on the latter. Our research is of significance for agricultural enterprises to raise their financial performance in Internet crowdfunding, especially for Chinese agricultural micro-enterprises.
\end{abstract}

Keywords: Internet crowdfunding; social network behaviors; financing performance; Internet finance; sustainability

\section{Introduction}

With the vigorous promotion of supply-side structural reform, agriculture, as an important basis of national economies, is facing an urgent task and reform pressure. At the same time, the overall mass innovation and entrepreneurship situation also injects innovation power into agriculture. Market opportunities in agriculture are actively explored to satisfy consumer demands, and efforts are made to realize the rapid growth and expansion of venture projects in agriculture by virtue of the strength of the capital market through financing. Moreover, the fast and effective promotion of these venture projects is very important in industrial upgrading and production efficiency promotion. It is favorable to relieve such problems as rising costs, putting the supply and demand structure out of balance, and increasing stock levels confronted by Chinese agriculture in recent years, thereby effectively conforming to fulfill the policy orientation of the Party Central Committee on adjusting and optimizing agricultural structure and effectively guaranteeing the supply of agricultural products [1]. 
Agriculture, a time-honored industry in China, has notable differentiating characteristics at the technology, product, and demand levels when compared with entrepreneurial activities in other fields. Due to such particularities, all of the existing research conclusions concerned with entrepreneurship shall be considered in combination with the special background of agriculture. Among the studies in the entrepreneurship field, a high-profile topic is how entrepreneurial leaders' social network behaviors affect the financing performance of venture projects and further control entrepreneurship performance [2,3]. Entrepreneurial leaders may, from the theoretical perspective of social network behaviors, attract attention from investors by various social network behaviors, e.g., disclosing information such as professional qualifications, abundant professional experience, and entrepreneurial experience, so as to establish legitimacy in the minds of investors or win investors' trust through deep interaction and communication with them [4].

However, our understanding of how social network behaviors affect entrepreneurial financing performance remains incomplete, and this is particularly true for different industries on online crowdfunding platforms, such as agriculture. Compared with venture projects in industries such as the information industry, it is more difficult to directly measure or present the technological and qualification levels of agricultural entrepreneurship by specific certificates or qualification; on the other hand, social network interactions between entrepreneurs and investors or customers will certainly result in different effects in different industries. The effect of social network behaviors on financing performance improvement also varies in different industries; however, at present, scholars have not proposed valid empirical evidence and academic interpretations. Most of the existing research in the entrepreneurship field are focused on the Internet industry or an industry-wide sampling research of national economies, and neglect the specificity of agriculture. Therefore, the existing research concerned with entrepreneurship cannot provide more targeted suggestions for entrepreneurs of agriculture, even though it is the basic but special industry of the national economy.

As indicated in the report of the 19th National Congress of the Communist Party of China, "we shall promote the deep integration of Internet, big data, artificial intelligence, and real economy". In the new era, the trend of combining agriculture and emerging technology becomes increasingly obvious, and entrepreneurial activities in agriculture also become increasingly vigorous. However, research on Internet entrepreneurship and financing in agriculture lag behind that of other industries; particularly, the existing research cannot carry out the targeted exploration of the specific effect of social network behaviors of entrepreneurs in this field on financing performance based on the characteristics of agriculture. In agriculture, many farmers are facing more severe resource constraints in the entrepreneurial process; thus, breaking free of resource constraints such as financing by virtue of their own social network resources becomes particularly important [5]. These unexplored traits of entrepreneurs' social network behaviors within online agricultural projects motivate our research question: Does the effect of entrepreneurs' social network behavior (including qualification information disclosure and social network interaction) on funding outcomes vary between agricultural and other industries?

To answer this research question, we developed a model to assess the effects of creators' social network behaviors within the crowdfunding setting, hypothesizing that: (1) the effect of disclosing qualification information on funding success in the agricultural industry is lower than that in other industries, while the effect of social network interaction behaviors is higher; and (2) the entrepreneurial team size reduces the above difference. To test our hypotheses, the propensity score matching method is adopted based on data of 7585 venture projects on authoritative Internet crowdfunding websites, the effects of social network behaviors of entrepreneurial leaders in agriculture on the financing performance of venture projects are analyzed, and the regulating effect of entrepreneurial team size on the said effect is discussed, thus providing a clearer explanation for the above mechanism. Our work offers contributions to the theoretical research of Internet entrepreneurship, especially for the difference between agricultural and other industries. 


\section{Theoretical Analysis and Research Hypotheses}

\subsection{Disclosure of Entrepreneurial Qualification Information and the Function of Social Network Interactions}

Research on the social network behaviors of entrepreneurs has always been a hot issue in entrepreneurship research; in particular, whether entrepreneurs in agriculture can preferably utilize their social network resources appropriately is important to entrepreneurship performance [2,3]. During the establishment and improvement of social networks by entrepreneurial leaders in the initial entrepreneurship stage, two kinds of social network behaviors may be seen by leaders and their social network members: the disclosure of qualification information and social network interaction. The disclosure of qualification information refers to the process of entrepreneurs initially disclosing their own qualifications and experience to establish their legitimacy and obtain the trust of network members [6]. Social network interaction refers to entrepreneurs actively carrying out information communication and feedback with social network members to improve the degree of embeddedness of their social networks [7]. The entrepreneurship performance brought by the aforesaid social network behaviors, such as legal information disclosure and social interaction, is of great importance in carrying out theoretical research and providing practical suggestions [4].

In the project, team members with past experience can help solve problems and challenges in the new project, and skills, knowledge, and a master's degree will positively impact the results of financing (Huckman et al., 2011) [8]. In the past, some scholars, from the perspective of signal theory, considered that entrepreneurial leader education, experience, and other information disclosure behaviors that can affect the capability assessment of potential investors can help leaders effectively establish their own entrepreneurship legitimacy and obtain the trust of other social network members [6]. Also, some scholars, from the perspective of social embeddedness theory, considered that social network interactions between entrepreneurial leaders and potential investors (e.g., social interactions, information communication, and information feedback) could help leaders establish and deepen the embeddedness between social network members [7]. Some scholars integrated either corporate social entrepreneurship or corporate entrepreneurship through corporate social responsibility (CSR) activities into their business models, and found a positive association between CSR and firm performance (Ştefan and Liliana, 2015) [9].

Generally, entrepreneurial leaders are simultaneously engaged in legal information disclosure and interaction in the social network communication process. Especially when facing potential investors, entrepreneurs are always confronted with the choice of two feasible social network strategies: to disclose the entrepreneurship-related qualification information of entrepreneurial leaders to investors as much as possible so as to establish their legitimacy in the minds of potential investors, or to disclose project progress and answer entrepreneurship-related questions of investors as much as possible via continuous social network interactions so as to strengthen the social network embeddedness and thereby obtain the trust of investors [10]. For venture projects in different industries, technical conditions, and social network conditions, the two kinds of social network behaviors have different functions. However, the existing academic research has not distinguished the differentiated effects of such social network behaviors on entrepreneurial leaders in different industries. The technology and product demands of entrepreneurs in agriculture are different from those of other industries. For example, scholars have analyzed the emerging entrepreneurial practices of family farms in Morocco, and have underlined the important role of a new generation of farmers in the emergence of entrepreneurial forms of agriculture [11]. However, the differentiated functions generated by such social network behaviors are not clearly revealed, and there are still certain "black-box" theories; therefore, a more in-depth analysis and exploration shall be carried out by utilizing theoretical and empirical research.

It is widely acknowledged that next to sound craftsmanship and management, farmers increasingly need entrepreneurship if they are to survive in modern agriculture, and there are three major factors driving farmers' entrepreneurial learning: redeveloping an entrepreneurial identity, 
crossing the boundaries of agriculture, and opening up the family farm (Pieter et al., 2013) [12]. In terms of social network behaviors in different industries, entrepreneurial leaders in agriculture always have a lower entrepreneurship threshold and more standardized product requirements, and it is difficult to quantify and present their entrepreneurial capability in agriculture with various types of qualification information. Whether entrepreneurship is successful or not is slightly related to qualification information, but it is highly related to entrepreneurial intention and the down-to-earth operation and accumulation in specific entrepreneurial processes. Some scholars have examined the interaction of two major themes in the restructuring process of European agriculture: the multifunctionality of agriculture and farmer entrepreneurship. The results describe a range of skills among farmers displaying a complex interaction between personal characteristics, enterprise type, and local socioeconomic and institutional conditions (Selyf et al., 2010) [13]. Cláudia and Mário (2018), through a case study of traditional black-eyed bean producers in a village in inland central Portugal, found that the interorganizational networks of agricultural entrepreneurs have played a fundamental role in developing this activity through horizontal, vertical, and collaborative networks with third parties [14]. For the disclosure of qualification information, such as the patent level of venture project products and the educational level and entrepreneurial experience of leaders, compared with venture projects in other industries, the legitimacy establishment effect for potential investors of venture projects in agriculture is lower, and potential investors are less sensitive to social network behaviors such as qualification information disclosure [15]. Therefore, the following hypotheses are proposed in this paper:

Hypothesis 1. The effect of the qualification information disclosure of entrepreneurial leaders on entrepreneurship financing performance in agriculture is lower than that in other industries.

Hypothesis 2. The effect of the patent information disclosure of venture projects on entrepreneurship financing performance is lower than that in other industries.

Hypothesis 3. The effect of the educational level information disclosure of entrepreneurial leaders on entrepreneurship financing performance in agriculture is lower than that in other industries.

Hypothesis 4. The effect of the entrepreneurial experience information disclosure of entrepreneurial leaders in agriculture on entrepreneurship financing performance is lower than that in other industries.

Moreover, based on social embeddedness theory and alluding to low technology level and a low standardized product, entrepreneurial leaders always select more social embeddedness and improve the relationship between social network members and entrepreneurial leaders through social network interaction [16]. According to research by Sun et al. (2015) [17] and by Colombo, Franzoni, and Rossi-Lamastra (2015) [18], the social network interactions of entrepreneurial leaders in agriculture, such as disclosing and updating information on venture project progress and answering questions proposed by potential investors, further helps them become integrated into potential investors' social networks, improves their social embeddedness level, and preferably mobilizes the social network to improve financing performance. Therefore, the following hypotheses are proposed in this paper:

Hypothesis 5. The effect of the social network interaction of entrepreneurial leaders on entrepreneurship financing performance in agriculture is higher than that in other industries.

Hypothesis 6. The effect of the project progress feedback of entrepreneurial leaders on entrepreneurship financing performance in agriculture is higher than that in other industries.

Hypothesis 7. The effects of project consultation and the answers of entrepreneurial leaders on entrepreneurship financing performance in agriculture are higher than those in other industries. 


\subsection{Regulating Effect of Entrepreneur Team Size}

Diversity of team culture is considered to be the collection of individual characteristics of team members based on their cultural characteristics (Joshi and Roh, 2009) [19]. Different types of cultural diversity influence the performance of entrepreneurs, such as gender diversity or demographic and ethnic diversity on the basis of the nationality of members of international diversity, and entrepreneurial member qualifications related to cultural diversity, such as diversity of knowledge and experience (Kearney, Gebert, and Voelpel, 2009) [20]. From the perspective of entrepreneurs' social network behaviors, team size always significantly facilitates the effectiveness of social network behaviors; meanwhile, improvement in team size always means a declining heterogeneous effect brought by qualification conditions and the social behaviors of individual entrepreneurs in different industries and venture projects [21]. In other words, improving the size and personnel diversity of entrepreneurial teams and the standardization of internal and external working processes will reduce the differentiated entrepreneurship advantages and disadvantages. On the one hand, in entrepreneurship research, team size always reflects the intention of entrepreneurs; compared with a small entrepreneurial team, a large team will require higher costs for establishment and maintenance, and have a stronger capability and comprehensive quality that is necessary for entrepreneurship [22]. According to the above discussion, entrepreneurship in agriculture is less standardized and more difficult to quantify compared with other fields, and it pays more attention to the down-to-earth attitude and strong operation capability in specific entrepreneurial processes. Moreover, a large entrepreneurial team size shows strong entrepreneurial intention and incentive to investors, is more diversified in educational background, experience, etc., and can attract more high-quality talents. Therefore, a large entrepreneurial team size contributes to making up insufficiencies in the qualification information disclosure of entrepreneurial leaders in agriculture, and strengthens the signal function of qualification information disclosure in the minds of investors, thereby making up the differences in the entrepreneurship performance improvement effect of the information disclosure of agricultural entrepreneurs compared with other industries [23]. The following hypotheses are proposed in this paper based on the aforesaid aspects:

Hypothesis 8. Expanding the entrepreneurial team size in agriculture can reduce the difference in the effect of the qualification information disclosure of entrepreneurial leaders on entrepreneurship financing performance compared with other industries.

Hypothesis 9. Expanding the entrepreneurial team size in agriculture can reduce the difference in the effect of the patent information disclosure of entrepreneurial leaders on entrepreneurship financing performance compared with other industries.

Hypothesis 10. Expanding the entrepreneurial team size in agriculture can reduce the difference in the effect of the educational level information disclosure of entrepreneurial leaders on entrepreneurship financing performance compared with other industries.

Hypothesis 11. Expanding the entrepreneurial team size in agriculture can reduce the difference in the effect of the entrepreneurial experience information disclosure of entrepreneurial leaders on entrepreneurship financing performance compared with other industries.

Meanwhile, along with the growth in team size and team members, the team also becomes more diversified [24]; moreover, human resources that are used for social network interactions will increase for both entrepreneurs of agricultural projects and those in other industries. Based on the demographic characteristics of entrepreneurial teams, cultural diversity can encourage teams to use more international and multicultural features of technology innovation or design change, establish a more effective decision-making mechanism, promote the production of a high-quality strategy, 
and meet the different cultural characteristics of the investment demands of investors (Cox, 1994) [25]. An increase in the manpower input in special customer relationships means the normalization of social network interactions between venture projects and potential investors, so the social network interactions of individual entrepreneurs will be gradually replaced by the social interactions of entrepreneurial teams and companies, and the advantages of individual social network interactions of agricultural projects will also decline. Therefore, the following hypotheses are proposed in this paper based on the aforesaid aspects:

Hypothesis 12. Expanding the entrepreneurial team size in agriculture can reduce the difference in the effect of the social network interaction of entrepreneurial leaders on entrepreneurship financing performance compared with other industries.

Hypothesis 13. Expanding the entrepreneurial team size in agriculture can reduce the difference in the effect of the project progress feedback of entrepreneurial leaders on entrepreneurship financing performance compared with other industries.

Hypothesis 14. Expanding the entrepreneurial team size in agriculture can reduce the difference in the effect of project consultation and the answers of entrepreneurial leaders in entrepreneurship financing performance compared with other industries.

Table 1 summarizes the findings for each hypothesis.

Table 1. Hypotheses.

\begin{tabular}{|c|c|}
\hline Hypothesis 1 & $\begin{array}{l}\text { The effect of the qualification information disclosure of entrepreneurial leaders in agriculture on } \\
\text { entrepreneurship financing performance is lower than that in other industries. }\end{array}$ \\
\hline Hypothesis 2 & $\begin{array}{l}\text { The effect of the patent information disclosure of venture projects on entrepreneurship financing performance } \\
\text { is lower than that in other industries. }\end{array}$ \\
\hline Hypothesis 3 & $\begin{array}{l}\text { The effect of the educational level information disclosure of entrepreneurial leaders on entrepreneurship } \\
\text { financing performance in agriculture is lower than that in other industries. }\end{array}$ \\
\hline Hypothesis 4 & $\begin{array}{l}\text { The effect of the entrepreneurial experience information disclosure of entrepreneurial leaders on } \\
\text { entrepreneurship financing performance in agriculture is lower than that in other industries. }\end{array}$ \\
\hline Hypothesis 5 & $\begin{array}{l}\text { The effect of the social network interaction of entrepreneurial leaders on entrepreneurship financing } \\
\text { performance in agriculture is higher than that in other industries. }\end{array}$ \\
\hline Hypothesis 6 & $\begin{array}{l}\text { The effect of the project progress feedback of entrepreneurial leaders on entrepreneurship financing } \\
\text { performance in agriculture is higher than that in other industries. }\end{array}$ \\
\hline Hypothesis 7 & $\begin{array}{l}\text { The effects of project consultation and the answers of entrepreneurial leaders on entrepreneurship financing } \\
\text { performance in agriculture are higher than those in other industries. }\end{array}$ \\
\hline Hypothesis 8 & $\begin{array}{l}\text { Expanding the entrepreneurial team size in agriculture can reduce the difference in the effect of the } \\
\text { qualification information disclosure of entrepreneurial leaders on entrepreneurship financing performance } \\
\text { compared with other industries. }\end{array}$ \\
\hline Hypothesis 9 & $\begin{array}{l}\text { Expanding the entrepreneurial team size in agriculture can reduce the difference in the effect of the patent } \\
\text { information disclosure of entrepreneurial leaders on entrepreneurship financing performance compared with } \\
\text { other industries. }\end{array}$ \\
\hline Hypothesis 10 & $\begin{array}{l}\text { Expanding the entrepreneurial team size in agriculture can reduce the difference in the effect of the } \\
\text { educational level information disclosure of entrepreneurial leaders on entrepreneurship financing } \\
\text { performance compared with other industries. }\end{array}$ \\
\hline Hypothesis 11 & $\begin{array}{l}\text { Expanding the entrepreneurial team size in agriculture can reduce the difference in the effect of the } \\
\text { entrepreneurial experience information disclosure of entrepreneurial leaders on entrepreneurship financing } \\
\text { performance compared with other industries. }\end{array}$ \\
\hline Hypothesis 12 & $\begin{array}{l}\text { Expanding the entrepreneurial team size in agriculture can reduce the difference in the effect of the social } \\
\text { network interaction of entrepreneurial leaders on entrepreneurship financing performance compared with } \\
\text { other industries. }\end{array}$ \\
\hline Hypothesis 13 & $\begin{array}{l}\text { Expanding the entrepreneurial team size in agriculture can reduce the difference in the effect of project } \\
\text { progress feedback of entrepreneurial leaders in entrepreneurship financing performance compared with } \\
\text { other industries. }\end{array}$ \\
\hline Hypothesis 14 & $\begin{array}{l}\text { Expanding the entrepreneurial team size in agriculture can reduce the difference in the effect of project } \\
\text { consultation and the answers of entrepreneurial leaders on entrepreneurship financing performance } \\
\text { compared with other industries. }\end{array}$ \\
\hline
\end{tabular}




\section{Research Design}

\subsection{Data Acquisition}

Data for this research were acquired from the Internet crowdfunding platform Indiegogo; this company is also a scientific finance enterprise that has attracted extensive attention in recent years. We have, by virtue of data-mining technology, sorted the information of 7585 financing projects in the "technology and innovation" column on this platform (1032 in 2014, 2209 in 2015, 2390 in 2016, and 2390 in 2017), and extracted the personal information of entrepreneurial leaders and the specific information of venture projects. Of those, 1031 are venture projects in agriculture, and 773 are from China (including 183 agricultural projects).

Indiegogo, the second largest Internet crowdfunding website in the world, launched more than 280,000 product venture projects in different industries and fields by the end of 2015. Kickstarter, the largest product crowdfunding website, was not used, because it does not accept crowdfunding projects from the Chinese mainland, and is averse to research on agricultural entrepreneurship (especially in China). In addition, there are two reasons for adopting Indiegogo: (1) this platform requires all registered venture project members to disclose partial basic personal information and accounts on social network sites and is favorable to further collecting the personal information of entrepreneurial leaders and relevant social network members, especially investors, in these accounts, thereby reflecting the effect of social network on financing more comprehensively; and (2) compared with other crowdfunding platforms, it proposes fewer restraints on customer types, thus highlighting the globalization and diversification of projects and enhancing the comprehensiveness and completeness of information.

\subsection{Variable Declaration}

(1) Dependent variable. The dependent variable in this paper is the financing performance of the venture project. On Indiegogo, entrepreneurs are asked to disclose the sales target of the project and take the quantity of products subscribed and paid by consumers by the end of a stipulated crowdfunding period as the actual sales amount. If the actual subscribed sales amount reaches the sales target, the crowdfunding project is deemed successful; otherwise, it is a failure, and payments by consumers are returned. As for this case, the calculation method for the financing performance of venture projects in this research is as follows: taking the financing success (Success) of an entrepreneurship crowdfunding project (criterion: the final subscribed investment amount is greater than or equal to the project financing objective, $n=2791$ ) and financing proportion (Proportion) (the proportion of final subscribed investment amount to project financing objective) as the dependent variables of financing performance [26]. Moreover, robustness verification was also carried out, with financing success (or not) as a dummy variable; for projects with subscriptions reaching the established sales target, the dummy variable is assigned as 1 , otherwise it is 0 .

(2) Explanatory variable. In this paper, first, whether a venture project is concerned with agriculture is determined according to its product description and classification; if it is, this variable is assigned as 1 , otherwise it is assigned as 0 , to generate a dummy variable of agricultural projects (Agri) $(\mathrm{n}=1032)$. According to research by Liu Gang, Wang Zeyu, and Cheng Xirong (2016) [26], the disclosure of the critical technical information of venture projects by entrepreneurial leaders enables investors to understand the venture project better and facilitate successful financing by the leaders. Therefore, products with patented technology will be assigned as 1, and other products will be assigned as 0 , thus further generating the patent information disclosure dummy variable (Patent) $(\mathrm{n}=4331)$, which is considered an explanatory variable. The educational background of the entrepreneurial leaders is also subject to value assignment. The education of entrepreneurial leaders is classified into four levels and replaced by corresponding values based on the educational information disclosed on the entrepreneurship financing platform: 3 for a doctorate degree, 2 for a Master's, 1 for a bachelor's degree, and 0 for any degree lower than bachelor's; this is the education information 
disclosure variable (Edu). For the entrepreneurial experience of team members, since the relevant social network site provides the occupational attributes of all of the entrepreneurial leaders, matching is carried out after deleting the unindicated or indicated but unidentifiable occupational information. Prior to launching this crowdfunding, where other entrepreneurship experience is used to express the previous entrepreneurial experience of leaders, it is assigned as 1 when experience is available, and 0 when it is unavailable, and this value is the entrepreneurial experience disclosure dummy variable (Exp).

As for social network interaction, the Internet crowdfunding website provides two ways for entrepreneurial leaders to develop targeted social interaction with potential investors: (1) The first is to release information on venture project progress on the social network site, which is different from the Internet entrepreneurship behaviors of the previous three kinds of information disclosure. The aforesaid venture project progress may be updated many times, and may be supplemented and revised according to the interested problems and demands of potential investors; it is a social network interaction reflecting the diligence of entrepreneurial leaders in venture projects and their response to the demands of potential investors. Therefore, in this paper, the amount of project progress feedback of entrepreneurial leaders at the completion of the project is regarded as the correlated variable of interaction on project progress feedback (Feedback) [27]. (2) Potential investors may raise questions to entrepreneurial leaders on Indiegogo, and leaders may answer by leaving messages; the rate of answering reflects how much attention entrepreneurial leaders paid to interacting with potential investors. The consultation and answering rate of entrepreneurial leaders before the completion of project financing is regarded as a variable measuring consultation and answer behaviors (Answer rate) in social network interaction [27].

(3) Regulating variable. Previous research showed that the number of entrepreneurial team members has a significant effect on financing performance. The larger the team, the more diversified the education and entrepreneurial experience of the members and the more diversified the technology and marketing capability, which covers the shortage of single entrepreneurial leaders in such aspects. Meanwhile, more members can assist the entrepreneurial team with adopting a more powerful strategy for social network interaction and reducing the effect of a single means of interaction provided by the platform through diversification. The number of team members publicized by leaders on the platform is regarded as the variable to measure team size [28].

(4) Control variable. Since the age and gender of entrepreneurial leaders as well as the application time of the crowdfunding website affect entrepreneurship performance, entrepreneurial leaders' age (Age), a gender dummy variable (Gender) $(n=5059)$, and the registration time of leaders on the platform (Regis) are considered control variables in this research. When the financing objective of a crowdfunding project on Indiegogo is indicated, the performance target $(\mathrm{USD} \times 104)$ of the project (Target) is limited and disclosed, and the purchase period (days) (Period) is opened; the above variables must have a certain effect on entrepreneurship success (or not) and performance. They are regarded as control variables in this research (see Table 2 for variable definitions and measurements, and Table 3 for statistical characteristics). 
Table 2. Variable definitions and measurements.

\begin{tabular}{|c|c|}
\hline Variable & Definition and Measurement \\
\hline \multicolumn{2}{|c|}{ Measures of financial performance } \\
\hline Proportion & The proportion of final subscribed investment amount to project financing objective. \\
\hline Success & $\begin{array}{l}\text { Project financial outcome dummy, which is assigned as } 1 \text { when the final subscribed investment amount is } \\
\text { greater than or equal to the project financing objective, and } 0 \text { otherwise. }\end{array}$ \\
\hline \multicolumn{2}{|c|}{ Measures of agriculture project } \\
\hline Agri & $\begin{array}{l}\text { Agriculture project dummy; it is assigned as } 1 \text { when a project is concerned with agriculture, which is } \\
\text { determined by product description and classification of the project, and } 0 \text { otherwise. }\end{array}$ \\
\hline \multicolumn{2}{|c|}{ Measures of qualification information disclosure } \\
\hline Patent & $\begin{array}{l}\text { Patent information disclosure dummy variable. Products with patented technology will be assigned as } 1 \text {, } \\
\text { and } 0 \text { otherwise. }\end{array}$ \\
\hline Edu & $\begin{array}{l}\text { Educational levels of entrepreneurial leaders. Based on the educational information disclosed on the } \\
\text { financing platform, it is assigned as } 3 \text { for a doctorate degree, } 2 \text { for a Master's, } 1 \text { for a bachelor's, and } 0 \text { for } \\
\text { lower than a bachelor's. }\end{array}$ \\
\hline Exp & $\begin{array}{l}\text { The dummy variable of experience, which is assigned as } 1 \text { when leaders have previous entrepreneurial } \\
\text { experience disclosed on their social network site, and } 0 \text { otherwise. }\end{array}$ \\
\hline \multicolumn{2}{|c|}{ Measures of social network interaction } \\
\hline Feedback & $\begin{array}{l}\text { The amount of project progress feedback of entrepreneurial leaders at the completion of the } \\
\text { crowdfunding project. }\end{array}$ \\
\hline Answer rate & The consultation and answering rate of entrepreneurial leaders before the completion of project financing. \\
\hline \multicolumn{2}{|l|}{ Regulating variable } \\
\hline Team size & The number of entrepreneurial team members publicized by entrepreneurial leaders on the platform. \\
\hline \multicolumn{2}{|l|}{ Control variable } \\
\hline Age & The entrepreneurial leader's age. \\
\hline Gender & The entrepreneurial leader's gender, which is assigned as 1 for male, and 0 for female. \\
\hline Regis & Registration time of entrepreneurial leaders in the crowdfunding platform. \\
\hline Target & The performance target that should be reached to start this project as set on the platform. \\
\hline Period & The purchase period of the project. \\
\hline
\end{tabular}

Table 3. Statistical characteristics of model.

\begin{tabular}{|c|c|c|c|c|c|c|c|c|c|c|c|c|c|c|}
\hline & $\begin{array}{c}1 . \\
\text { Proportion } \\
(\%)\end{array}$ & $\begin{array}{c}2 . \\
\text { Success }\end{array}$ & 3. Agri & $\begin{array}{l}4 . \\
\text { Patent }\end{array}$ & $\begin{array}{c}5 . \\
\text { Edu }\end{array}$ & $\begin{array}{c}6 . \\
\text { Exp }\end{array}$ & $\begin{array}{c}7 . \\
\text { Feedback } \\
\text { (Piece) }\end{array}$ & $\begin{array}{l}\text { 8. Answer } \\
\text { Rate (\%) }\end{array}$ & $\begin{array}{l}\text { 9. Team } \\
\text { Size (n) }\end{array}$ & $\begin{array}{l}\text { 10. Age } \\
\text { (Years) }\end{array}$ & $\begin{array}{c}11 . \\
\text { Gender }\end{array}$ & $\begin{array}{c}12 . \\
\text { Regis } \\
\text { (Month) }\end{array}$ & $\begin{array}{c}\text { 13. Target } \\
\left(\text { USD } \times 10^{4}\right)\end{array}$ & $\begin{array}{c}14 . \\
\text { Period } \\
\text { (Day) }\end{array}$ \\
\hline Avg. & 2.875 & 0.368 & 0.136 & 0.571 & 1.947 & 0.371 & 4.785 & 0.109 & 6.773 & 30.177 & 0.667 & 17.176 & 3.690 & 26.15 \\
\hline S.D. & 1.441 & 0.426 & 0.167 & 0.406 & 2.015 & 0.406 & 6.707 & 0.457 & 5.086 & 24.28 & 0.577 & 28.763 & 4.478 & 7.091 \\
\hline Min. & 0 & 0 & 0 & 0 & 0 & 0 & 1 & 0 & 1 & 18 & 0 & 9 & 0.5 & 10 \\
\hline Max. & 27.86 & 1 & 1 & 1 & 3 & 0.75 & 27 & 1 & 25 & 78 & 1 & 78 & 150 & 90 \\
\hline
\end{tabular}

\subsection{Measurement Model}

To test our hypotheses, we estimated ordinary least squares (OLS) regression, which is conducted according to the following model:

$$
D V=\alpha+\sum \beta(I D V s)+\sum \gamma(\text { controls })+\varepsilon
$$

where $D V$ is a dependent variable (financing proportion), IDVs is an explanatory variable and regulating variable, controls is a control variable, and $\varepsilon$ is the model residual. In order to verify the hypotheses, three-way interaction is adopted in this paper. We input the interaction between dummy variables and other explanatory variables of the agricultural project to verify hypotheses 1 to 5 , then input the interaction between dummy variables and regulating variables of the agricultural project, between regulating variables and other explanatory variables, and the three-way interaction among dummy variables, other explanatory variables, and regulating variables of agricultural projects to verify hypotheses 8 to 14 .

To further carry out robustness verification, the dummy variable of successful financing is regarded as a dependent variable, and Probit regression is adopted to conduct robustness verification. 


\section{Model Regression Result and Analysis}

In this research, the correlation coefficient between variables is verified by Stata software (see Table 4 for specific results). A relatively significant correlation coefficient exists between the explanatory variables and dependent variables selected for this research according to the correlation coefficient matrix between variables, and most of the correlation coefficients between explanatory variables and control variables are less than 0.3 . Therefore, the correlation level between explanatory variables and control variables is relatively low, thus avoiding the multicollinearity of the model.

Table 4. Correlation coefficients of model.

\begin{tabular}{lccccccccccccc}
\hline & $\mathbf{1}$ & $\mathbf{2}$ & $\mathbf{3}$ & $\mathbf{4}$ & $\mathbf{5}$ & $\mathbf{6}$ & $\mathbf{7}$ & $\mathbf{8}$ & $\mathbf{9}$ & $\mathbf{1 0}$ & $\mathbf{1 1}$ & $\mathbf{1 2}$ & $\mathbf{1 3}$ \\
\hline 1. Proportion & 1 & & & & & & & & & & & & \\
2. Success & 0.016 & 1 & & & & & & & & & & \\
3. Agri & 0.092 & -0.226 & 1 & & & & & & & & & \\
4. Patent & 0.195 & 0.082 & 0.016 & 1 & & & & & & & & \\
5. Edu & 0.002 & -0.209 & 0.181 & 0.076 & 1 & & & & & & & \\
6. Exp & 0.012 & 0.026 & 0.013 & 0.239 & 0.014 & 1 & & & & & & \\
7. Feedback & 0.074 & 0.013 & -0.018 & 0.035 & 0.008 & 0.013 & 1 & & & & & \\
8. Answer rate & 0.013 & 0.033 & 0.028 & 0.025 & 0.085 & 0.022 & 0.011 & 1 & & & & \\
9. Team size & 0.161 & 0.007 & 0.058 & 0.026 & 0.027 & 0.017 & 0.018 & -0.003 & 1 & & & \\
10. Age & 0.096 & 0.050 & 0.091 & 0.234 & 0.007 & 0.102 & 0.051 & 0.036 & 0.014 & 1 & & \\
11. Gender & 0.244 & 0.100 & 0.013 & 0.349 & 0.144 & 0.059 & 0.078 & 0.028 & -0.062 & 0.032 & 1 & \\
12. Regis & 0.241 & 0.079 & 0.261 & 0.002 & 0.419 & 0.149 & 0.13 & 0.205 & 0.170 & 0.037 & 0.201 & 1 \\
13. Target & 0.414 & 0.151 & 0.195 & 0.491 & 0.210 & 0.264 & 0.009 & 0.072 & 0.117 & 0.023 & 0.015 & 0.090 & 1 \\
14. Period & 0.145 & 0.130 & 0.208 & 0.213 & 0.194 & 0.079 & 0.185 & 0.152 & 0.147 & 0.043 & 0.026 & 0.110 & 0.093 \\
\hline
\end{tabular}

To further test the robustness of the study results, according to research by Deng and Wang (2016), this paper use Z-statistics to test hypotheses 1 and 2 (see Table 5 for the output results) [29].

Table 5. Regression results for action difference between the social network behaviors of agricultural projects and other project financing, with subsample regression.

\begin{tabular}{|c|c|c|}
\hline & Model 1 & Model 2 \\
\hline & Agricultural Projects & Nonagricultural Projects \\
\hline Agri & $\begin{array}{c}-0.010^{* * *} \\
(0.002)\end{array}$ & $\begin{array}{c}-0.009 * * * \\
(0.004)\end{array}$ \\
\hline Patent & $\begin{array}{l}0.026^{* *} \\
(0.013)\end{array}$ & $\begin{array}{c}0.070 * * * \\
(0.011)\end{array}$ \\
\hline Z-statistics & \multicolumn{2}{|c|}{$2.584^{* * *}$} \\
\hline Edu & $\begin{array}{c}0.003 \\
(0.003)\end{array}$ & $\begin{array}{c}0.011 \\
(0.001)\end{array}$ \\
\hline Z-statistics & \multicolumn{2}{|c|}{$2.530^{* * *}$} \\
\hline Exp & $\begin{array}{c}0.026^{* * *} \\
(0.010)\end{array}$ & $\begin{array}{c}0.098^{* * *} \\
(0.020)\end{array}$ \\
\hline Z-statistics & \multicolumn{2}{|c|}{$3.220^{* * *}$} \\
\hline Feedback & $\begin{array}{c}0.002 \\
(0.002)\end{array}$ & $\begin{array}{c}0.003 * * * \\
(0.001)\end{array}$ \\
\hline Z-statistics & \multicolumn{2}{|c|}{$1.689 *$} \\
\hline Answer rate & $\begin{array}{l}0.038^{*} \\
(0.020)\end{array}$ & $\begin{array}{c}0.145^{* * *} \\
(0.020)\end{array}$ \\
\hline Z-statistics & \multicolumn{2}{|c|}{3.783} \\
\hline Team size & $\begin{array}{c}0.004^{* * *} \\
(0.001)\end{array}$ & $\begin{array}{c}0.004^{* * *} \\
(0.001)\end{array}$ \\
\hline Other control variables & Including & Including \\
\hline R-square & 0.391 & 0.419 \\
\hline $\mathrm{F}$ & 13.87 & 434.55 \\
\hline Observed value & 1032 & 6553 \\
\hline
\end{tabular}

Note: (1) Proportion is regarded as a dependent variable; (2) the ordinary least squares (OLS) model is adopted; $(3)^{*}, * *$, and ${ }^{* * *}$ represent the significance of the Z-statistics at $10 \%, 5 \%$, and $1 \%$, respectively. 
Moreover, regression analysis is conducted on the data of the crowdfunding project with Stata software. First, an analysis is conducted to see whether there is any difference in the financing performance action between the information disclosure behavior in relevant agricultural venture projects and the social network interaction compared with other projects. All of the explanatory variables and the interaction between dummy variables and other explanatory variables of agricultural projects are input into the model to verify the research hypotheses. Due to limited length, the output results (see Table 5 for details) of the other control variables are omitted.

From the regression results in Table 6, both the explanatory variables and regulating variables adopted in this paper have a significant regression effect on financing proportion, in which, compared with other projects, the overall financing performance of agricultural projects is poorer and has a negative effect. A significant negative regression coefficient is provided for the interaction between three quality information disclosure behaviors (patent information disclosure, educational level disclosure, and entrepreneurial experience disclosure) and the dummy variables of agricultural projects. Therefore, the effect of the above legal information disclosure behaviors in agricultural projects is lower than that of other projects. Thus, hypotheses $2-4$ are verified, and Hypothesis 1 is verified completely. In addition, a positive significant regression coefficient is provided for the interaction between two social network interactions, project progress feedback and consultation and answer, and a dummy variable of agriculture information, which proves that the social network interactions of agricultural projects make greater contributions to entrepreneurship financing performance than other projects. Thus, hypotheses 6 and 7 are proved through the regression result, and Hypothesis 5 is verified.

Table 6. Regression results of action difference between the social network behaviors of agricultural projects and other project financing.

\begin{tabular}{|c|c|c|c|c|}
\hline & Model 1 & Model 2 & Model 3 & Model 4 \\
\hline Agri & $\begin{array}{c}-0.011^{* * *} \\
(0.002)\end{array}$ & $\begin{array}{c}-0.009 * * * \\
(0.003)\end{array}$ & $\begin{array}{c}-0.011^{* * *} \\
(0.002)\end{array}$ & $\begin{array}{c}-0.010^{* * *} \\
(0.001)\end{array}$ \\
\hline Patent & $\begin{array}{c}0.054^{* * *} \\
(0.009)\end{array}$ & $\begin{array}{c}0.052 * * * \\
(0.028)\end{array}$ & $\begin{array}{c}0.051 * * \\
(0.023)\end{array}$ & $\begin{array}{c}0.053^{* * *} \\
(0.027)\end{array}$ \\
\hline Edu & $\begin{array}{l}0.007^{* *} \\
(0.003)\end{array}$ & $\begin{array}{c}0.006 \\
(0.004)\end{array}$ & $\begin{array}{l}0.006 \text { * } \\
(0.003)\end{array}$ & $\begin{array}{c}0.006 \\
(0.004)\end{array}$ \\
\hline Exp & $\begin{array}{c}0.078^{* * *} \\
(0.011)\end{array}$ & $\begin{array}{c}0.076^{* * *} \\
(0.012)\end{array}$ & $\begin{array}{c}0.068^{* * *} \\
(0.009)\end{array}$ & $\begin{array}{c}0.079 * * * \\
(0.014)\end{array}$ \\
\hline Feedback & $\begin{array}{c}0.002 \text { *** } \\
(0.001)\end{array}$ & $\begin{array}{c}0.002 \text { *** } \\
(0.001)\end{array}$ & $\begin{array}{c}0.002 \text { *** } \\
(0.001)\end{array}$ & $\begin{array}{c}0.002 \text { *** } \\
(0.001)\end{array}$ \\
\hline Answer rate & $\begin{array}{l}0.101 * * \\
(0.017)\end{array}$ & $\begin{array}{c}0.122 * * * \\
(0.018)\end{array}$ & $\begin{array}{c}0.1 \\
(0.068)\end{array}$ & $\begin{array}{c}0.099 \\
(0.070)\end{array}$ \\
\hline Team size & $\begin{array}{c}0.004^{* * *} \\
(0.001)\end{array}$ & $\begin{array}{c}0.004^{* * *} \\
(0.001)\end{array}$ & $\begin{array}{c}0.005^{* * *} \\
(0.001)\end{array}$ & $\begin{array}{c}0.004^{* * *} \\
(0.001)\end{array}$ \\
\hline Patent $\times$ Agri & & $\begin{array}{c}-0.002 * * * \\
-0.001\end{array}$ & & $\begin{array}{c}-0.002 * * * \\
-0.001\end{array}$ \\
\hline Edu $\times$ Agri & & $\begin{array}{c}-0.001 * * \\
(0.001)\end{array}$ & & $\begin{array}{c}-0.001 * * \\
(0.001)\end{array}$ \\
\hline Exp $\times$ Agri & & $\begin{array}{c}-0.006^{* * *} \\
(0.002)\end{array}$ & & $\begin{array}{c}-0.005^{* * *} \\
(0.002)\end{array}$ \\
\hline Feedback $\times$ Agri & & & $\begin{array}{c}0.001 * * * \\
\left(5.07 \times 10^{-5}\right)\end{array}$ & $\begin{array}{c}0.001^{* *} \\
\left(3.26 \times 10^{-4}\right)\end{array}$ \\
\hline Answer rate $\times$ Agri & & & $\begin{array}{c}0.079 * * * \\
(0.021)\end{array}$ & $\begin{array}{c}0.072 * * * \\
(0.015)\end{array}$ \\
\hline Other control variables & Including & Including & Including & Including \\
\hline R-square & $0.41^{\circ}$ & 0.602 & 0.452 & 0.521 \\
\hline $\mathrm{F}$ & 13.87 & 434.55 & 428.04 & 493.45 \\
\hline Observed value & 7585 & 7585 & 7585 & 7585 \\
\hline
\end{tabular}

Note: (1) Proportion is regarded as a dependent variable; (2) OLS model is adopted; (3) ${ }^{*}, * *$, and ${ }^{* * *}$ represent the significance of the Z-statistic quantity at $10 \%, 5 \%$, and $1 \%$, respectively. 
Moreover, three-way interaction is adopted, whereby the interactions of any two variables among dummy variables, other explanatory variables, and the regulating variables of agricultural projects as well as the common interaction of the three variables are input into models to analyze Hypotheses 8-14. Similarly, only the regression results (see Table 7 for details) for dummy variables and other explanatory variables as well as the three-way interaction of agricultural projects are output due to limited length.

Table 7. Regression results for the regulating effect of team size.

\begin{tabular}{|c|c|c|c|}
\hline & Model 1 & Model 2 & Model 3 \\
\hline Patent $\times$ Agri & $\begin{array}{l}-0.002 * * * \\
(0.001)\end{array}$ & $\begin{array}{l}-0.002 * * * \\
(0.001)\end{array}$ & $\begin{array}{l}-0.002 * * * \\
(0.001)\end{array}$ \\
\hline Edu $\times$ Agri & $\begin{array}{c}-0.001^{* * *} \\
\left(2.35 \times 10^{-4}\right)\end{array}$ & $\begin{array}{c}-0.001^{* * *} \\
\left(2.02 \times 10^{-4}\right)\end{array}$ & $\begin{array}{l}-0.001 \\
(0.001)\end{array}$ \\
\hline Exp $\times$ Agri & $\begin{aligned}-0.004^{* * *} & (0.002)\end{aligned}$ & $\begin{array}{c}-0.004^{* * *} \\
(0.001)\end{array}$ & $\begin{array}{c}-0.005^{* * *} \\
(0.002)\end{array}$ \\
\hline Feedback $\times$ Agri & $\begin{array}{c}0.001^{* *} \\
\left(2.10 \times 10^{-4}\right)\end{array}$ & $\begin{array}{c}0.001^{* *} \\
\left(1.93 \times 10^{-4}\right)\end{array}$ & $\begin{array}{l}0.001 * \\
(0.001)\end{array}$ \\
\hline Answer rate $\times$ Agri & $\begin{array}{l}0.051^{* * *} \\
(0.020)\end{array}$ & $\begin{array}{l}0.047^{* * *} \\
(0.019)\end{array}$ & $\begin{array}{c}0.049^{* * *} \\
(0.015)\end{array}$ \\
\hline Patent $\times$ Agri $\times$ Team size & $\begin{array}{c}1.17 \times 10^{-4 * * *} \\
\left(1.34 \times 10^{-5}\right)\end{array}$ & & $\begin{array}{c}1.29 \times 10^{-4 * * *} \\
\left(1.17 \times 10^{-5}\right)\end{array}$ \\
\hline Edu $\times$ Agri $\times$ Team size & $\begin{array}{l}2.22 \times 10^{-4 *} \\
\left(1.09 \times 10^{-4}\right)\end{array}$ & & $\begin{array}{c}2.29 \times 10^{-4 * * *} \\
\left(7.29 \times 10^{-5}\right)\end{array}$ \\
\hline Exp $\times$ Agri $\times$ Team size & $\begin{array}{c}3.34 \times 10^{-4 * * *} \\
\left(6.76 \times 10^{-5}\right)\end{array}$ & & $\begin{array}{c}3.28 \times 10^{-4 * * *} \\
\left(5.54 \times 10^{-5}\right)\end{array}$ \\
\hline Feedback $\times$ Agri $\times$ Team size & & $\begin{array}{c}-2.48 \times 10^{-4 * * *} \\
\left(4.38 \times 10^{-6}\right)\end{array}$ & $\begin{array}{c}-2.79 \times 10^{-4 * * *} \\
\left(6.21 \times 10^{-5}\right)\end{array}$ \\
\hline Answer rate $\times$ Agri $\times$ Team size & & $\begin{array}{l}-0.011^{* * *} \\
(0.002)\end{array}$ & $\begin{array}{l}-0.009 * * \\
(0.004)\end{array}$ \\
\hline Other control variables & Including & Including & Including \\
\hline R-square & 0.44 & 0.419 & 0.404 \\
\hline $\mathrm{F}$ & 421.79 & 398.98 & 401.27 \\
\hline Observed value & 7585 & 7585 & 7585 \\
\hline
\end{tabular}

Note: (1) Proportion is regarded as a dependent variable; (2) OLS model is adopted; (3) ***, and ${ }^{* * *}$ represent the significance of the Z-statistic at $10 \%, 5 \%$, and $1 \%$, respectively.

From the regression results in Table 7, a significant positive effect exists in the three-way interaction among team size, quality information disclosure behaviors (patent information disclosure, educational level disclosure, and entrepreneurial experience disclosure), and the dummy variables of agricultural projects. Compared with other projects, the difference of legal information financing action for agricultural projects may be remedied with a bigger team size and higher diversity among entrepreneurial members. Thus, Hypotheses $9-11$ and Hypothesis 8 are verified. Similarly, a negative significant coefficient exists for the three-way interaction among team size, social network interactions (project progress feedback and consultation and answer), and the dummy variables of agricultural projects, proving that bigger team size and interaction diversity and more members may also reduce the entrepreneurship financing advantage of social network interaction in agricultural projects when compared with other projects.

For a robustness test, regression is conducted with financing success as a dependent variable through the Probit model. From the robustness analysis results in Table 8, a significant negative regression coefficient is provided for the interaction between the three qualification information disclosure behaviors and dummy variables of agricultural projects, and a significant positive regression coefficient for the interaction between two social network interaction behaviors and the dummy variables of agricultural projects, which verifies Hypotheses 1 (and 2-4) and 5 (and 6,7). Moreover, the results of three-way interaction reveal that a positive significant coefficient is provided for team size, three qualification information disclosure behaviors, and the dummy variables of agricultural 
projects, verifying Hypothesis 8 (and 9-11). Besides, a negative significant coefficient exists for the three-way interaction among team size, two social network interaction behaviors, and the dummy variables of agricultural projects, verifying Hypothesis 12 (and 13,14). Therefore, we conclude that our original findings are reasonably robust.

Table 8. Robustness analysis results: Probit model.

\begin{tabular}{|c|c|c|c|}
\hline & Model 1 & Model 2 & Model 3 \\
\hline Agri & $\begin{array}{c}-0.003^{* * *} \\
(0.001)\end{array}$ & $\begin{array}{c}-0.003^{* * *} \\
(0.001)\end{array}$ & $\begin{array}{l}-0.002 \\
(0.002)\end{array}$ \\
\hline Patent & $\begin{array}{c}0.008^{* * *} \\
(0.002)\end{array}$ & $\begin{array}{c}0.007^{* *} \\
(0.003)\end{array}$ & $\begin{array}{c}0.008^{* * *} \\
(0.002)\end{array}$ \\
\hline Edu & $\begin{array}{l}0.004^{* * *} \\
(0.001)\end{array}$ & $\begin{array}{l}0.004^{* * *} \\
(0.001)\end{array}$ & $\begin{array}{l}0.004^{* * *} \\
(0.001)\end{array}$ \\
\hline Exp & $\begin{array}{l}0.021^{* * *} \\
(0.006)\end{array}$ & $\begin{array}{l}0.018^{* * *} \\
(0.007)\end{array}$ & $\begin{array}{l}0.022 * * \\
(0.011)\end{array}$ \\
\hline Feedback & $\begin{array}{c}0.001^{* * *} \\
\left(2.45 \times 10^{-4}\right)\end{array}$ & $\begin{array}{c}0.001^{* * *} \\
\left(2.26 \times 10^{-4}\right)\end{array}$ & $\begin{array}{c}0.001^{* * *} \\
\left(3.45 \times 10^{-4}\right)\end{array}$ \\
\hline Answer rate & $\begin{array}{c}0.027^{* * *} \\
(0.002)\end{array}$ & $\begin{array}{c}0.021^{* * *} \\
(0.005)\end{array}$ & $\begin{array}{c}0.015^{* * *} \\
(0.002)\end{array}$ \\
\hline Team size & $\begin{array}{c}0.001^{* * *} \\
\left(1.17 \times 10^{-4}\right)\end{array}$ & $\begin{array}{c}0.001 * * * \\
\left(3.08 \times 10^{-4}\right)\end{array}$ & $\begin{array}{c}0.001 \\
(0.001) \\
\end{array}$ \\
\hline Patent $\times$ Agri & & $\begin{array}{c}-0.001^{* * *} \\
\left(3.78 \times 10^{-5}\right)\end{array}$ & $\begin{array}{c}-0.001^{* * *} \\
\left(3.60 \times 10^{-5}\right)\end{array}$ \\
\hline Edu $\times$ Agri & & $\begin{array}{c}-3.04 \times 10^{-4 * * *} \\
\left(5.66 \times 10^{-5}\right)\end{array}$ & $\begin{array}{l}-3.04 \times 10^{-4} \\
\left(2.88 \times 10^{-4}\right)\end{array}$ \\
\hline Exp $\times$ Agri & & $\begin{array}{l}-0.001 * \\
(0.001)\end{array}$ & $\begin{array}{l}-0.001 \\
(0.002)\end{array}$ \\
\hline Feedback $\times$ Agri & & $\begin{array}{l}4.05 \times 10^{-4 * * *} \\
\left(4.39 \times 10^{-5}\right)\end{array}$ & $\begin{array}{l}3.23 \times 10^{-4 * *} \\
\left(7.78 \times 10^{-5}\right)\end{array}$ \\
\hline Answer rate $\times$ Agri & & $\begin{array}{l}0.011^{* * *} \\
(0.004)\end{array}$ & $\begin{array}{l}0.011^{* * *} \\
(0.005)\end{array}$ \\
\hline Patent $\times$ Agri $\times$ Team size & & & $\begin{array}{l}1.29 \times 10^{-4 * * *} \\
\left(1.17 \times 10^{-5}\right)\end{array}$ \\
\hline Edu $\times$ Agri $\times$ Team size & & & $\begin{array}{c}2.29 \times 10^{-4 * * *} \\
\left(7.29 \times 10^{-5}\right)\end{array}$ \\
\hline Exp $\times$ Agri $\times$ Team size & & & $\begin{array}{c}3.28 \times 10^{-4 * * *} \\
\left(5.54 \times 10^{-5}\right)\end{array}$ \\
\hline Feedback $\times$ Agri $\times$ Team size & & & $\begin{array}{c}-2.79 \times 10^{-4 * * *} \\
\left(6.21 \times 10^{-5}\right)\end{array}$ \\
\hline Answer rate $\times$ Agri $\times$ Team size & & & $\begin{array}{c}-0.009 * * \\
(0.004)\end{array}$ \\
\hline Other control variables & Including & Including & Including \\
\hline Pseudo R-square & 0.31 & 0.208 & 0.249 \\
\hline Log likelihood & 372.98 & 410.54 & 401.97 \\
\hline Observed value & 7585 & 7585 & 7585 \\
\hline
\end{tabular}

Note: (1) Success is regarded as a dependent variable; (2) Probit model is adopted; (3)****, and ${ }^{* * *}$ represent the significance of the Z-statistic at $10 \%, 5 \%$, and $1 \%$, respectively.

Last, regression was conducted for all of the Chinese venture projects separately to investigate whether the relevant hypotheses and conclusions are applicable to the theoretical and practical situations of Chinese agricultural entrepreneurship; see Table 9 for specific regression results. All of the hypotheses in this paper are verified according to the relevant empirical evidence; the model not only provides high robustness, it also indicates that the relevant hypotheses and theoretical discussions are applicable to the rural economic and entrepreneurial background of China. 
Table 9. Robustness analysis results: Chinese projects.

\begin{tabular}{|c|c|c|c|}
\hline & Model 1 & Model 2 & Model 3 \\
\hline Agri & $\begin{array}{c}-0.013 * * * \\
(0.003)\end{array}$ & $\begin{array}{c}-0.011^{* * *} \\
(0.004)\end{array}$ & $\begin{array}{l}-0.008 \\
(0.006)\end{array}$ \\
\hline Patent & $\begin{array}{c}0.007^{* * *} \\
(0.002)\end{array}$ & $\begin{array}{c}0.029 * * \\
(0.014)\end{array}$ & $\begin{array}{l}0.009 * \\
(0.006)\end{array}$ \\
\hline Edu & $\begin{array}{l}0.008^{* * *} \\
(0.002)\end{array}$ & $\begin{array}{l}0.007^{*} \\
(0.004)\end{array}$ & $\begin{array}{c}0.008^{* * * *} \\
(0.001)\end{array}$ \\
\hline Exp & $\begin{array}{l}0.020^{* * *} \\
(0.005)\end{array}$ & $\begin{array}{l}0.055^{* * *} \\
(0.011)\end{array}$ & $\begin{array}{l}0.016^{*} \\
(0.010)\end{array}$ \\
\hline Feedback & $\begin{array}{l}0.001 * * \\
(0.001)\end{array}$ & $\begin{array}{l}0.002 * * \\
(0.001)\end{array}$ & $\begin{array}{l}0.001 * \\
(0.001)\end{array}$ \\
\hline Answer rate & $\begin{array}{l}0.033^{* * *} \\
(0.006)\end{array}$ & $\begin{array}{l}0.028^{* * *} \\
(0.007)\end{array}$ & $\begin{array}{l}0.029^{* * *} \\
(0.008)\end{array}$ \\
\hline Team size & $\begin{array}{c}0.001^{* * *} \\
\left(1.88 \times 10^{-4}\right)\end{array}$ & $\begin{array}{c}0.004^{* * *} \\
(0.001)\end{array}$ & $\begin{array}{c}0.001 * * \\
(0.001)\end{array}$ \\
\hline Patent $\times$ Agri & & $\begin{array}{c}-0.004^{* * *} \\
(0.002)\end{array}$ & $\begin{array}{l}-0.001 * \\
(0.001)\end{array}$ \\
\hline Edu $\times$ Agri & & $\begin{array}{c}-0.001 * * \\
(0.001)\end{array}$ & $\begin{array}{c}-0.001 * * \\
(0.001)\end{array}$ \\
\hline Exp $\times$ Agri & & $\begin{array}{c}-0.008^{* * *} \\
(0.003)\end{array}$ & $\begin{array}{l}-0.006 \\
(0.004)\end{array}$ \\
\hline Feedback $\times$ Agri & & $\begin{array}{l}0.002 * * \\
(0.001)\end{array}$ & $\begin{array}{l}3.23 \times 10^{-4 * *} \\
\left(7.78 \times 10^{-5}\right)\end{array}$ \\
\hline Answer rate $\times$ Agri & & $\begin{array}{l}0.078^{* * *} \\
(0.026)\end{array}$ & $\begin{array}{c}0.035^{* * *} \\
(0.007)\end{array}$ \\
\hline Patent $\times$ Agri $\times$ Team size & & & $\begin{array}{c}5.56 \times 10^{-5 * * *} \\
\left(3.34 \times 10^{-6}\right)\end{array}$ \\
\hline Edu $\times$ Agri $\times$ Team size & & & $\begin{array}{c}4.15 \times 10^{-5 * * *} \\
\left(2.88 \times 10^{-6}\right)\end{array}$ \\
\hline Exp $\times$ Agri $\times$ Team size & & & $\begin{array}{c}1.29 \times 10^{-4 * * *} \\
\left(3.11 \times 10^{-5}\right)\end{array}$ \\
\hline Feedback $\times$ Agri $\times$ Team size & & & $\begin{array}{c}-8.11 \times 10^{-5 * * *} \\
\left(2.02 \times 10^{-5}\right)\end{array}$ \\
\hline Answer rate $\times$ Agri $\times$ Team size & & & $\begin{array}{c}-0.003 * * * \\
(0.001)\end{array}$ \\
\hline Other control variables & Including & Including & Including \\
\hline R-square & 0.311 & 0.289 & 0.321 \\
\hline $\mathrm{F}$ & 74.71 & 69.69 & 70.01 \\
\hline Observed value & 773 & 773 & 773 \\
\hline
\end{tabular}

Note: (1) Proportion is regarded as a dependent variable; (2) OLS model is adopted; (3) ${ }^{* * *}$, and ${ }^{* * *}$ represent the significance of the Z-statistic at $10 \%, 5 \%$, and $1 \%$, respectively.

\section{Study Conclusion and Contributions}

In this paper, the effect of qualification information disclosure and social network interactions on the financing performance of entrepreneurial leaders in agriculture is deeply researched based on the mining and analysis of Internet crowdfunding data. The uniqueness of entrepreneurship in agriculture is effectively revealed, and the following research conclusions and enlightenments are obtained:

First, compared with other industries, the effect of qualification information disclosure on the financing performance of entrepreneurial leaders in agriculture is lower, whereas the effect of social network interaction is higher. Based on this research conclusion, we suggest that entrepreneurial leaders in agriculture pay more attention to timely disclosing project financing progress and answering and providing feedback on the relevant questions of investors so as to conduct effective social network interactions, thereby improving financing performance.

Second, a bigger team size may reduce the difference in the effect of qualification information disclosure on the financing performance of entrepreneurial leaders in agriculture compared with other industries, improving the relative efficiency of qualification information disclosure. Meanwhile, expanding team size will also reduce the difference in the effect of social network interaction on 
the financing performance of entrepreneurial leaders in agriculture compared with other industries, weakening the relative efficiency of social network interaction. Based on this research conclusion, we suggest that entrepreneurial leaders in agriculture enhance the effectiveness of qualification information disclosure by expanding team size so that qualification information disclosure can more effectively improve the level of financing performance.

Third, crowdfunding, a new financing mode for Chinese agricultural enterprises under new circumstances, has been a concern by domestic scholars; however, focusing on specific case analysis, such as in studies by Hu Jixiang (2004) [30] and Zhu Lijing (2016) [31], a systemic analysis of financing performance and its effect factors is unavailable. Seen from the separate regression analysis of Chinese crowdfunding projects, no inhomogeneity exists in the above research conclusions. The relevant research conclusions of international crowdfunding are also applicable to Chinese projects, and no significant disadvantage occurs in the international crowdfunding performance of Chinese projects in the existing research [32]. Based on this point, it is suggested that Chinese agricultural enterprises exert a crowdfunding advantage to improve their financing performance level by reference to the above research conclusion, especially for small and micro-agricultural enterprises.

This paper contributes to the theoretical system and research ideas of entrepreneurship research in agriculture. On one hand, this paper enriches the existing theoretical research of entrepreneurship in agriculture, makes an innovative investigation into the Internet financing performance and its effect on the factors of entrepreneurship in agriculture, and finds certain differences in effect caused by the uniqueness of agriculture compared with other industries. On the other hand, from the aspect of research ideas, this paper uses a data-mining method to carry out a mining arrangement and analysis of the data of an Internet crowdfunding platform, so as to more effectively capture the effect relationship of entrepreneurial leaders' information disclosure and social network interactions on a company's financial performance. This research enriches the literature on Internet financing performance and its effect factors for Chinese entrepreneurship in agriculture; from the statistical results, no difference characteristic occurs in this research, so the research conclusions are of universal practical significance.

The present study has limitations that offer avenues for future research. First, this research verifies the relative efficiency of entrepreneurial team size on enhancing the qualification information disclosure and improving financing performance by introducing the variable of entrepreneurial team size, thereby reducing the difference in the effect of the qualification information disclosure of entrepreneurial leaders in agriculture on financing performance compared with other industries. However, the expansion of team size generally increases corresponding management cost and difficulty; especially for companies with limited resources, advantages and disadvantages shall be weighed to judge whether teams need to be expanded to strengthen the effect of information disclosure. Consequently, the increased cost generated in expanding team size may be incorporated into the model, and a U-shape or inverted U-shape relationship may be explored in future research. Second, our research collected data in an online crowdfunding platform by data mining, with no focus on the offline entrepreneurship setting. Also, this research pays more attention to the effect of entrepreneurial leaders' qualification information disclosure and social network interactions on financing, and insufficient attention to the subsequent entrepreneurial process after financing and final performance; therefore, an offline questionnaire tracking process may be expanded in future research to reveal the relationship between agricultural entrepreneurs' behaviors and entrepreneurship performance.

Author Contributions: Writing: Z.Y.; providing case and idea: K.W., Z.-Y.W., S.-B.T.; Revising and editing: J.Y., G.L.

Funding: This research was funded by [Tianjin City philosophy and social science planning] grant number [TJGL17-004] and Zhongshan City Science and Technology Bureau Project (No. 2017B1015).

Conflicts of Interest: The authors declare no conflict of interest. 


\section{References}

1. Zhang, S.; Shi, R.; Yu, A. Analysis of Function Optimization for Wholesale Market of Agricultural Products under Agricultural Supply-side Reform. J. Beijing Technol. Bus. Univ. Soc. Sci. 2016, 31, 10-16.

2. Huang, J.; Cai, G.; Mai, Y. Rural Micro Enterprises: Entrepreneurs' Social Capital and Start-ups Performance. Chin. Rural Econ. 2010, 5, 65-73.

3. Zhu, Y. Agricultural Innovation Adoption and Diffusion on View of Social Network. Chin. Rural Econ. 2016, 9, 58-71.

4. Shafigullina, A.V.; Palyakin, R.B. Social media marketing as an effective instrument of the promotion of social business-project in social entrepreneurial activity. Acad. Mark. Stud. J. 2016, 20, 1-8.

5. Guo, H.; Ding, G. Relationship Network, Opportunity Innovation and Farmer Entrepreneurship Performance. Chin. Rural Econ. 2013, 8, 78-87.

6. Murphy, P.J.; Kickul, J.; Barbosa, S.D.; Titus, L. Expert capital and perceived legitimacy female-run entrepreneurial venture signalling and performance. Int. J. Entrep. Innov. 2007, 8, 127-139.

7. Jack, S.L.; Anderson, A.R. The effects of embeddedness on the entrepreneurial process. J. Bus. Ventur. 2002, 17, 467-487. [CrossRef]

8. Huckman, R.S.; Staats, B.R. Fluid Tasks and Fluid Teams: The Impact of Diversity in Experience and Team Familiarity on Team Performance. Manuf. Serv. Oper. Manag. 2011, 13, 310-328. [CrossRef]

9. Gherghina, S..C.; Simionescu, L.N. Does Entrepreneurship and Corporate Social Responsibility Act as Catalyst towards Firm Performance and Brand Value? Int. J. Econ. Financ. 2015, 4, 23-34. [CrossRef]

10. Aral, S.; Walker, D. Tie strength, embeddedness, and social influence: A large-scale networked experiment. Manag. Sci. 2014, 60, 1352-1370. [CrossRef]

11. Petit, O.; Kuper, M.; Ameur, F. From worker to peasant and then to entrepreneur? Land reform and agrarian change in the Saïss (Morocco). World Dev. 2018, 5, 119-131. [CrossRef]

12. Seuneke, P.; Lans, T.; Wiskerke, J.S.C. Moving beyond entrepreneurial skills: Key factors driving entrepreneurial learning in multifunctional agriculture. J. Rural Stud. 2013, 12, 208-219. [CrossRef]

13. Morgan, S.L.; Marsden, T.; Miele, M. Adrian Morley-Agricultural multifunctionality and farmers' entrepreneurial skills: A study of Tuscan and Welsh farmers. J. Rural Stud. 2010, 2, 116-129. [CrossRef]

14. Diasa, C.; Franco, M. Cooperation in tradition or tradition in cooperation? Networks of agricultural entrepreneurs. Land Use Policy 2018, 71, 36-48. [CrossRef]

15. Giones, F.; Miralles, F. Do actions matter more than resources? A signalling theory perspective on the technology entrepreneurship process. Technol. Innov. Manag. Rev. 2015, 5, 39-45. [CrossRef]

16. Ravindran, K.; Susarla, A.; Mani, D.; Gurbaxani, V. Social capital and contract duration in buyer-supplier networks for information technology outsourcing. Inf. Syst. Res. 2015, 26, 379-397. [CrossRef]

17. Sun, Y.; Wang, N.; Shen, X.L.; Zhang, J.X. Location information disclosure in location-based social network services. Comput. Hum. Behav. 2015, 52, 278-292. [CrossRef]

18. Colombo, M.G.; Franzoni, C.; Rossi-Lamastra, C. Internal social capital and the attraction of early contributions in crowdfunding. Entrep. Theory Pract. 2015, 39, 75-100. [CrossRef]

19. Joshi, A.; Roh, H. The Role of Context in Work Team Diversity Research: A Meta-Analytic Review. Acad. Manag. J. 2009, 52, 599-627. [CrossRef]

20. Eric, K.; Diether, G. Managing diversity and enhancing team outcomes: The promise of transformational leadership. J. Appl. Psychol. 2009, 94, 77-89.

21. Kotha, R.; George, G. Friends, Family, or fools: Entrepreneur experience and its implications for equity distribution and resource mobilization. J. Bus. Ventur. 2012, 27, 525-543. [CrossRef]

22. Haleblian, J.; Finkelstein, S. Top management team size, CEO dominance, and firm performance: The moderating roles of environmental turbulence and discretion. Acad. Manag. J. 1993, 36, 844-863.

23. Tohidi, H.; Tarokh, M.J. Productivity outcomes of teamwork as an effect of information technology and team size. Int. J. Prod. Econ. 2006, 103, 610-615. [CrossRef]

24. Shu, C.; Simmons, S.A. firm survival in traded industries: Does localization moderate the effects of founding team experience? Small Bus. Econ. 2018, 50, 643-656. [CrossRef]

25. Cox, T.C. The implementation of cultural diversity in police organizations: A group antagonism perspective. J. Police Crim. Psychol. 1994, 10, 41-46. [CrossRef] 
26. Liu, G.; Wang, Z.; Cheng, X. "Friend Network" Advantages, In-group Features and Internet Entrepreneurship-Based on an New Integrated View of Social Identify and Embeddedness Theory. China Ind. Econ. 2016, 8, 110-126.

27. Mollick, E. The dynamics of crowdfunding: An exploratory study. J. Bus. Ventur. 2012, 29, 1-16. [CrossRef]

28. Zhao, Y.L.; Song, M.; Storm, G.L. Founding team capabilities and new venture performance: The mediating role of strategic positional advantages. Entrep. Theory Pract. 2013, 37, 789-814. [CrossRef]

29. Deng, Z.; Wang, Z. Early-mover advantages at cross-border business-to-business e-commerce portals. J. Bus. Res. 2016, 69, 6002-6011. [CrossRef]

30. $\mathrm{Hu}, \mathrm{J}$. Localization Development Exploration of Crowdfunding. Secur. Mark. Her. 2014, 4, 10-15.

31. Zhu, L. Agricultural Crowdfunding is Creating "Blue Sea”. Mark. Ind. Agric. Mater. Mark. 2014, $23,45-47$.

32. Zheng, H.; Li, D.; Wu, J.; Xu, Y. The role of multidimensional social capital in crowdfunding: A comparative study in China and US. Inf. Manag. 2014, 51, 488-496. [CrossRef]

C 2018 by the authors. Licensee MDPI, Basel, Switzerland. This article is an open access article distributed under the terms and conditions of the Creative Commons Attribution (CC BY) license (http:// creativecommons.org/licenses/by/4.0/). 